originalni

naučni

rad

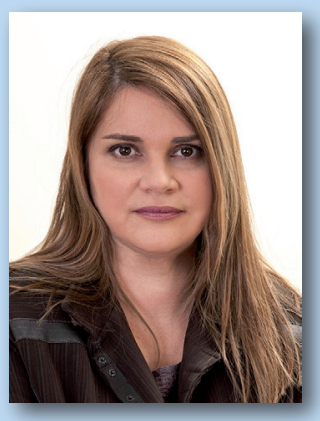

mr Nataša Krstić

Centar za visoke ekonomske studije Beograd krstic.natasa@gmail.com

\title{
SOCIJALNO PREDUZETNIŠTVO
}

\section{Rezime}

Socijalno preduzetništvo doživelo je u poslednjoj deceniji renesansu u svetu. Poslovni sektor, pritisnut ekonomskom krizom i imperativima društvene odgovornosti, počeo je da se okreće održivijim organizacionim modelima, koji u sebi objedinjavaju dobitnu i odgovornu orijentaciju. Socijalno preduzetništvo u celini karakteriše podrška i pomoć zajednici ili osetljivim društvenim grupama. Socijalni preduzetnici predstavljaju dokaz da finansijski uspeh ne isključuje odgovorno ponašanje prema društvenoj zajednici i životnoj sredini, kao i da društveno-koristan cilj može da bude uspešan poslovni pokretač. Ujedno, socijalna preduzeća mogu biti veoma koristan izvor preduzetničkih ideja u ekonomijama koje prolaze kroz tranziciju, sa visokim stopama nezaposlenosti. Popunjavanje praznina u pružanju određenih društvenih usluga, uz istovremeno ostvarivanje dobiti i mogućnost angažovanja čitave porodice, samo su neke od odlika socijalnih preduzeća, koja bi mogla da postanu jedan od vodećih modela privređivanja i u srpskoj privredi.

Ključne reči: socijalno preduzetništvo, socijalno preduzeće, socijalni preduzetnici, preduzetništvo, društveni ciljevi, društveno odgovorno poslovanje

JEL: A13, L21, L26, M14 


\section{SOCIAL \\ ENTREPRENEURSHIP}

\section{Summary}

Social entrepreneurship has experienced a renaissance in the world over the last decade. The business sector, pressed by the economic crisis and social responsibility imperatives, started to turn towards some of the more sustainable organisational models, which combine profit and responsible orientation. Social entrepreneurship, as a whole, is characterised by the support and assistance rendered to the community and the vulnerable social groups. Social entrepreneurs are a proof that financial success does not exclude responsible behaviour towards the social community and the environment, and that the socially beneficial target may also serve as a successful business driver. At the same time, social enterprises may be a very useful source of entrepreneurial ideas in the economies which are passing through transition, with the high unemployment rates. Filling in the gaps in offering certain social services, with simultaneous profit making and offering option for engagement of entire families, are only some of the features characteristic for the social enterprises, which could become one of the leading models of business conducted in the Serbian economy.

Key words: social entrepreneurship, social enterprise, social entrepreneurs, entrepreneurship, social targets, corporate social responsibility

JEL: A13, L21, L26, M14

\section{Nataša Krstić, MSc}

Centre for Higher Economic Studies, Belgrade rrstic.natasa@gmail.com 
"Socijalni preduzetnici ne žele da pomognu. Oni žele da promene svet"

Ašoka (Ashoka)

\section{Socijalno preduzetništvo - biznis ili nužda?}

Socijalno preduzetništvo je inovativan način za rešavanje različitih ekonomskih, obrazovnih, zdravstvenih i ekoloških problema u zajednici putem rada - udruživanjem i korišćenjem održivih poslovnih modela. U organizacionom pogledu, socijalno preduzetništvo je praktično isto kao i poslovanje sa ciljem ostvarenja dobiti; ne predstavlja dobrotvornu organizaciju, već privređivanje koje funkcioniše na bazi tržišnog načina razmišljanja, sa sopstvenim proizvodima, uslugama, kupcima, tržištima, troškovima i prihodima.

Socijalno preduzeće pak podrazumeva poslovanje sa idejom da kroz zaradu koju ostvaruje putem prodaje proizvoda/usluga ispuni jasno opredeljenu društvenu misiju. Ono je dobitno, samo-održivo, ima društvenokorisne ciljeve, a ostvarenu dobit koristi za rešavanje društvenih, ili problema koji se tiču životne sredine (British Council, „Socijalno preduzetništvo - biznis u službi zajednice“). Iako njegov cilj nije isti kao kod klasičnih preduzeća, rukovodioci socijalnog preduzeća razmišljaju i rade različito od dobrotvornih ili nevladinih organizacija. Pokušavajući da u isto vreme ostvare svoje društvene ciljeve, socijalna preduzeća moraju da pokriju svoje troškove, kako bi bila samofinansirajuća i održiva na duži rok. Međutim, za razliku od klasičnih preduzeća gde se dobit najčešće isplaćuje investitorima, prihodi koji su ostvareni iz socijalnog preduzeća reinvestiraju se $u$ poslovanje, i na taj način stavljaju na raspolaganje ciljnoj grupi korisnika $u$ vidu niže cene, pristupačnije i bolje usluge. $\mathrm{U}$ tom domenu, nalazi se i osnovna razlika $\mathrm{u}$ odnosu na nevladine organizacije, od kojih većina nije stvorena sa ciljem da samostalno pokriva troškove svog poslovanja, te je upućena da uloži deo svog vremena i energije u prikupljanje novčanih donacija.

Socijalno preduzeće razlikuje se i od društveno odgovornog poslovanja. Preduzeća koja strateški primenjuju društveno odgovorno poslovanje nastoje da umanje negativne efekte svojih poslovnih delatnosti po društveno i prirodno okruženje. Socijalna preduzeća osnovana su sa prevashodnim ciljem da ostvare pozitivan uticaj na ljude i prirodno okruženje.

Treba praviti razliku i između socijalnih preduzeća i udruženja građana, po nekoliko bitnih kriterijuma (Smart kolektiv, 2013):

- komercijalni/tržišni fokus koji koriste socijalna preduzeća da bi postigla svoj društveni i/ili ekološki cilj,

- kupci, koji su u fokusu socijalnog preduzeća koje treba da proizvodi proizvode/pruža usluge za kojima postoji tražnja na tržištu,

- uticaj tržišta na razvoj poslovanja, kojim se udaljava od društvene potrebe na kojoj je zasnovana poslovna ideja,

- dugoročno planiranje, pri čemu socijalno preduzeće obično priprema plan poslovanja za 3-5 narednih godina, sa ciljem razvoja svog udela na tržištu.

U literaturi se za prepoznavanje socijalnih preduzeća i njihovo jasno profilisanje često koriste kriterijumi koje su razradili istraživači evropskog istraživačkog instituta EMES (European Research Network), po kojima da bi se organizacija smatrala socijalnim preduzećem, treba da poseduje sledeće odlike (Grupa 484, 2010, str. 3):

- postoji stalna delatnost proizvodnje i prodaje roba i usluga,

- preduzeće je samostalno u odnosu na državni i privatni sektor,

- svesno preduzima ekonomski rizik kako bi ostvarilo sopstvene prihode,

- zapošljava određeni, minimalni broj plaćenih radnika; dobrovoljci takođe učestvuju u radnim aktivnostima,

- postoji jasno preduzimanje poslovnih aktivnosti zarad ostvarivanja učinka i koristi za društvo ili određenu marginalizovanu grupaciju,

- preduzeće je nastalo i deluje kao posledica organizovane i solidarne akcije, upravljanje preduzećem je zasnovano na principu „jedan član - jedan glas",

- korisnici učestvuju u upravljačkoj strukturi preduzeća,

- postoje jasna pravila i praksa ograničene raspodele dobiti.

Socijalni preduzetnici su pak pojedinci koji 
"Social entrepreneurs do not wish to help. They wish to change the world"

Ashoka

\section{Social entrepreneurship - business or necessity?}

Social entrepreneurship is a novel way of addressing various economic, educational, health, and ecological issues in a community through work - joining together and use of sustainable business models. Organisationally, social entrepreneurship is practically the same as the business with the aim to make profit; it is not a charitable organisation but a business process that functions with the market oriented mindset, with its own products, consumers, markets, costs and revenues.

Social enterprise, however, is the profitdriven business with the idea to fulfil, through profit made by sale of products/services, its clearly defined social mission. It is a profitable, self-sustainable enterprise, socially beneficial targets oriented, that its profit made is used for solving social or environmental problems (British Council - "Social Entrepreneurship Business in Service of Community"). Although its target is not the same as that of the classic enterprise, social enterprise managers are having a different mindset than those of the humanitarian or non-governmental organisations. While striving to simultaneously achieve their social targets, social enterprises must cover their own costs, in order to be selffinanced and sustainable over a longer period of time. However, contrary to the classic companies where profits are most often paid to investors, revenues acquired from the social enterprise are being reinvested in business, and in this way they are being placed at the disposal of the targeted group of beneficiaries, in the form of lower priced, or more accessible and better services. In this field, there is the basic difference also to be found with respect to the non-governmental organisations, the majority of which was not established with the aim of independently covering its operating costs, and is forced to invest a part of its time and effort in collecting donation funds.

Social enterprise is different also from the corporate social responsibility. Companies that strategically apply corporate social responsibility are striving to reduce negative effects of their business activities on the social and natural environment. On the other hand, social enterprises are formed with the primary objective of achieving a positive effect on people and natural habitat.

It is necessary to draw a difference between the social enterprises and the citizens' associations along several significant criteria (Smart Collective2013):

- commercial/market focus used by social enterprises in order to achieve their social and/or environmental target;

- consumers, who are in the focus of the social enterprise that must produce products/offer services for which there is a market demand;

- market impact on business development, that would distance the enterprise from the social necessity on which the business idea is based;

- long-term planning where the social enterprise is usually preparing business plan for the next 3-5 years, with the aim of developing its market share;

What is used in literature for identifying social enterprises and their clear profiling are often the criteria created by the researchers of the European Research Network - EMES, which stipulate that in order for an organisation to be recognised as a social enterprise it is necessary for it to comprise the following features (Group 484,2010, p. 3):

- There must be a constant production and selling of goods or services;

- The enterprise is autonomous in relation to public and private sectors;

- Full awareness of undertaking economic risk in order to achieve own income;

- The enterprise employs certain, minimum number of paid workers, and also volunteers participate in activities of social enterprises;

- Business activities are clearly undertaken in order to achieve the social impact and benefits to society or to a marginalised group;

- Enterprise is established and is operating as the consequence of an organised and solidarity action, with the enterprise management based on the "one member one vote" principle; 
nude inovativna rešenja za goruće društvene probleme, pri čemu je društvena komponenta najvažniji element njihovog poslovanja. Ukoliko bi se izvršilo poređenje između pojma i karakteristika klasičnih sa socijalnim preduzetnicima, zaključuje se da je osnovni cilj klasičnog preduzetnika da ostvari ekonomske koristi, dok je prioritet kod socijalnog ispunjenje društvene misije.

Tabela navedena ispod pokazuje jedinstvene odlike klasičnih, dobitno-usmerenih preduzetnika naspram socijalnih preduzetnika, i prikazuje karakteristike zajedničke za obe vrste preduzetništva. koga je profesor Danijel Bel (Daniel Bell) sa Harvarda opisao kao najuspešnijeg svetskog preduzetnika u sferi socijalnog preduzetništva zbog svoje uloge u osnivanju više od 60 novih organizacija širom sveta, uključujući i Školu za socijalne preduzetnike (School for Social Entrepreneurs - SSE), koja podržava pojedince da ostvare svoj individualni potencijal, osnuju i održe socijalna preduzeća i poslovanje zasnovano na društvenim komponentama. Takođe, vredno je izdvojiti i inicijativu Univerziteta Stenford iz 2004. godine, nazvanu „Društvena laboratorija" (Social. E. Lab), коja promoviše upotrebu preduzetničkih principa u svrhu

Tabela 1: - Jedinstvene i zajedničke karakteristike preduzetnika usmerenih isključivo ka stvaranju dobiti u odnosu na socijalne preduzetnike (Abu-Saifan S., 2012):

\begin{tabular}{|c|c|c|}
\hline $\begin{array}{l}\text { Jedinstvene karakteristike } \\
\text { preduzetnika usmerenih na dobit }\end{array}$ & Zajedničke karakteristike & $\begin{array}{l}\text { Jedinstvene karakteristike } \\
\text { socijalnih preduzetnika }\end{array}$ \\
\hline $\begin{array}{l}\text { visoki ciljevi } \\
\text { preuzimanje rizika } \\
\text { organizacione sposobnosti } \\
\text { strateško razmišljanje } \\
\text { stvaranje vrednosti } \\
\text { celishodan pristup }\end{array}$ & $\begin{array}{l}\text { inovativnost } \\
\text { posvećenost } \\
\text { preduzimanje inicijative } \\
\text { liderstvo } \\
\text { reakcija na prilike } \\
\text { upornost } \\
\text { posvećenost }\end{array}$ & $\begin{array}{l}\text { lider u ostvarenju društvene misije } \\
\text { emotivno angažovan } \\
\text { donosi odluke/promene u društvu } \\
\text { stvara društvenu vrednost } \\
\text { osetljiv na probleme društva } \\
\text { vizionar } \\
\text { veoma odgovoran }\end{array}$ \\
\hline
\end{tabular}

\section{Istorijat socijalnog preduzetništva}

Iako je socijalno preduzetništvo relativno nov pojam, njegove tragove možemo naći kroz istoriju razvoja preduzetništva, imajući u vidu dugu tradiciju ekonomskih preduzeća sa socijalnim ciljevima u svetu. Dobrotvorna udruženja datiraju još iz srednjeg veka, a dugu istoriju takođe imaju i poljoprivredne zadruge, kreditne unije, uzajamna društva, zadužbine i fondacije. Spisak znamenitih ličnosti uz čiji rad možemo dodati epitet "socijalni preduzetnik“ obuhvata Florens Najtigejl (Florence Nightingale), osnivačicu prve škole za bolničarke, Roberta Ovena (Robert Owen), osnivača zadružnog pokreta i Vinoba Beva (Vinoba Bhave-a), ispred pokreta za poklanjanje indijske zemlje (India's Land Gift Movement). Tokom XIX i XX veka, neki od najuspešnijih preduzetnika uspešno su prevazišli građanske, regulatorne i poslovne probleme promovisanjem ideja koje su preuzeli od javnih službi, poput bolnica ili škola. Od 1950-1990. godine, vodeći promoter socijalnog preduzetništva bio je Majkl Jang (Michael Young), rešavanja društvenih i ekoloških problema, i koji je do sada razvio nekoliko priznatih inicijativa, poput Drip Teh (Drip Tech), Projekta zdrava deca (Project Healthy Children) i Zagrljaj (Embrace). Ostali primeri dobro organizovanih socijalnih preduzeća u svetu bili bi Ašoka (Ashoka), Zdravlje za jedan svet (OneWorld Health) i Švab fondacija za socijalno preduzetništvo (Schwab Foundation for Social Enterpreneurship). Danas, možda najpoznatije socijalno preduzeće je Gramen Grupa (Grameen Group), čiji je osnivač Muhamad Junus (Muhammad Yunus) dobitnik Nobelove nagrade za mir 2006. godine. Gramen grupa posluje u vidu mreže koju čini 30 sestrinskih preduzeća povezanih sa Bangladeš Gramen bankom (Bangladeshi Grameen Bank), začetnikom ideje mikrokreditiranja, koja je do danas odobrila kredite u iznosu od preko 7, 5 miliona evra siromašnim ljudima, od kojih $97 \%$ predstavljaju žene. 
- Beneficiaries participate in the management structure of social enterprises;

- There are clear rules and practice related to limited distribution of profit.

Social entrepreneurs are the individuals offering novel solutions for the urgent social problems, where the social component is the most important element of their business. If comparison is to be made between the notion and characteristics of the classic with the social entrepreneurs, the conclusion would be that that the main purpose of a classic entrepreneur is to make economic gain, while the priority of the social entrepreneur is to fulfil the social mission.

Table that follows presents particular characteristics of the classis, profit oriented entrepreneurs, in comparison with the social entrepreneurs, and shows characteristics that are common for both of these types of entrepreneurs. heading the India's Land Gift Movement. During the 19th and the 20th century, some of the most successful entrepreneurs had successfully mastered civic, regulatory and business problems by promoting the ideas that they had adopted from public services, such as hospitals and schools. From 1950-1999, the leading promoter of social entrepreneurship was Michael Young, who was described by Daniel Bell, professor at the Harvard University, as the most successful world entrepreneur in the sphere of social entrepreneurship, due to his role in establishment of more than 60 new organisations throughout the world, including the School for Social Entrepreneurs - SSF, which is supporting individuals to realise their individual potential, establish and sustain social enterprises and the business based on social components. In addition, it is worth to note the initiative of the Stanford University of

Table 1: Particular and common characteristics of entrepreneurs aimed exclusively at the profit making, in respect to the social entrepreneurs (Abu-Saifan S., 2012):

\begin{tabular}{|l|l|l|}
\hline $\begin{array}{l}\text { Particular characteristics of the } \\
\text { profit-making entrepreneurs }\end{array}$ & Common features & $\begin{array}{l}\text { Particular characteristics of the } \\
\text { social entrepreneurs }\end{array}$ \\
\hline $\begin{array}{l}\text { High targets } \\
\text { Risk taking }\end{array}$ & $\begin{array}{l}\text { Innovation } \\
\text { Organisational skills }\end{array}$ & $\begin{array}{l}\text { Leadication in social mission } \\
\text { achievement }\end{array}$ \\
Strategic thinking & Taking initiative & Emotionally engaged \\
Value creation & Leadership & Makes decisions/changes in society \\
Meaningful approach & Reaction to circumstances & Creates social value \\
& Persistence & Sensitive to society problems \\
& Dedication & Visionary \\
& & Very responsible \\
\hline
\end{tabular}

\section{History of Social Entrepreneurship}

Although social entrepreneurship is a relatively new notion, its roots may be traced back through history of entrepreneurship development, bearing in mind long tradition of commercial enterprises with social objectives in the world. Charitable associations date as far back as the Middle Ages, and the long history is also the feature of agrarian cooperatives, credit unions, mutual societies, endowments and foundations. The list of distinguished personalities with their work deserving of the epithet "social entrepreneur" comprises Florence Nightingale, the founder of the first school for nurses, Robert Owen, founder of the cooperative movement, and Vinoba Bhave, the year 2004, called the "Social Laboratory" (Social, E. Lab) which is promoting application of entrepreneurial principle in the solution of social and environmental problems, and which has developed so far several recognised initiatives, the likes of Drip Tech, Project Healthy Children, and Embrace. Other examples of well organised social enterprises in the world would be the Ashoka, One World Health, and the Schwab Foundation for Social Entrepreneurship. Today, perhaps the best known social enterprise is the Grameen Group, whose founder Muhammad Yunus is the Nobel Peace Prize winner for the year 2006. Gramee Group is operating in the form of a network composed of 30 sister companies connected with the Bangladeshi Grameen bank, the 


\section{Socijalna preduzeća u Evropskoj uniji}

U Zapadnoj Evropi, socijalna preduzeća se prvi put pojavljuju krajem 70. godina prošlog veka, kada je došlo do prvih pojavnih oblika nemogućnosti države da svojom regulacijom zadovolji potrebe svih građana, izbori se sa problemom rastuće nejednakosti i socijalne inkluzije, većinom prouzrokovanih smanjenjem ekonomskog rasta i zapošljavanja. Rastući interes za socijalna preduzeća koji se javlja u poslednje vreme, uslovljen je prepoznavanjem njihovih kapaciteta da se izbore sa ekonomskim i društvenim problemima koje javni i poslovni sektor nisu u stanju da reše. U Evropi trenutno postoji preko 40 različitih oblika udruživanja u oblasti socijalne ekonomije, sa inovativnim pristupima ka rešavanju problema u domenu socijalnih usluga, poput obrazovanja, zdravstva, zaštite životne sredine, stanovanja i fer uslova na tržištu. Po obasti delovanja, evropskokontinentalna društvena preduzeća možemo razvrstati u tri grupe (Grupa 484, 2010):

- preduzeća koja pružaju usluge ugroženim kategorijama stanovništva, ili usluge od javnog interesa (npr. briga o deci, osobama sa invaliditetom, centri za dnevne boravke, pomoć u kući).

- preduzeća koja se bave radnom integracijom pripadnika teško zapošljivih i marginalizovanih društvenih grupa, koja nude proizvode/usluge na tržištu, a dobit

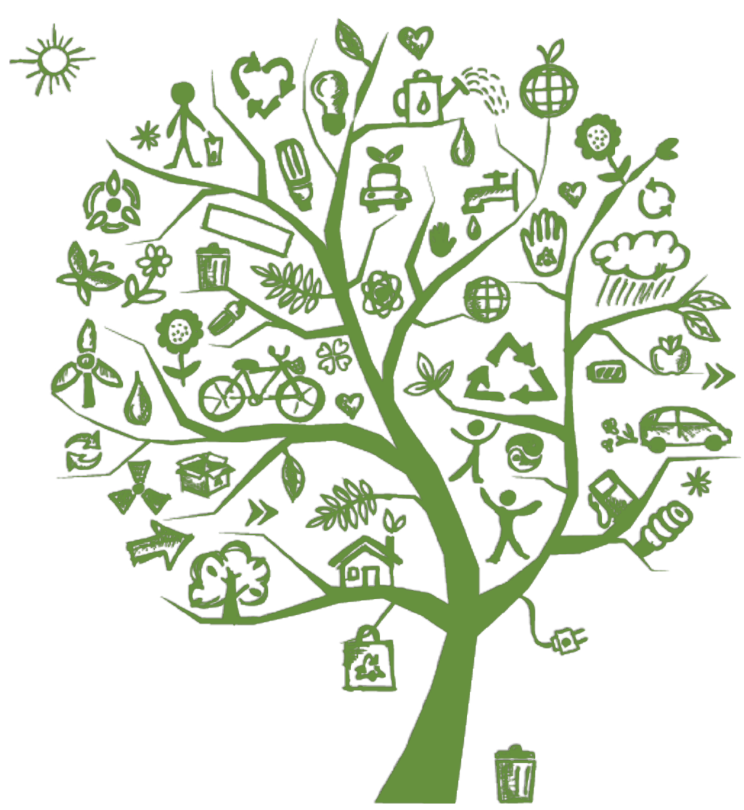

usmeravaju na dodatnu obuku svojih članova i poboljšanje njihovog društvenog položaja. Da bi preduzeće ostvarilo fiskalne olakšice i dobilo status socijalnog preduzeća, kao kriterijum se određuje minimalan broj ljudi iz marginalizovanih grupacija $u$ ukupnom broju zaposlenih.

- preduzeća koja rade $\mathrm{u}$ netradicionalnim oblastima za socijalnu ekonomiju, poput lokalnog razvoja, pružanja kulturnih usluga, zaštiti životne sredine, reciklaži, i sl.

Procenjuje se da sektor socijalnog preduzetništva u svetu danas zapošljava oko 40 miliona ljudi, pri čemu u Evropskoj uniji različiti oblici socijalnog preduzetništva čine oko 2 miliona privrednih društava, što predstavlja $10 \%$ od ukupnog broja. Kada je u pitanju Velika Britanija, socijalna preduzeća danas čine približno 5\% svih preduzeća i sa zaradom od preko 8 milijardi funti godišnje stvaraju oko $1 \%$ godišnjeg nacionalnog proizvoda zemlje. $U$ Italiji je 1991. godine uvedena forma "društvene zadruge" (ital. "Cooperative sociale"), kako bi se definisao pravni okvir za pojedine delatnosti socijalnih preduzeća, prvenstveno u oblasto socijalnih usluga i zapošljavanja pripadnika ugroženih kategorija društva. U pitanju je dominantna forma društvenog preduzeća u Italiji, sa 200.000 zaposlenih, 1,5 miliona korisnika i stopom rasta od $15-30 \%$ godišnje. U Portugalu je pak uvedena forma „zadruge društvene solidarnosti“ (port. "Cooperativas de solidariedade social"), koja pruža podršku ugroženim kategorijama društva i nerazvijenim društvenim zajednicama. Francuska je 2001. uvela formu „zadružnog društva zajedničkog interesa" (fra. "Societe cooperative dinteret collectif"), prepoznajući značaj socijalnog preduzetništva po nacionalnu ekonomiju. U pogledu finansiranja, socijalna preduzeća imaju prioritet $\mathrm{u}$ regionalnoj politici Evropske unije, kroz Evropski socijalni fond i Evropski regionalni fond za razvoj.

Može se reći da su neki od razloga sve veće zastupljenosti socijalnih preduzeća u svetu sledeći faktori (Smart kolektiv, 2013):

- ekonomska kriza, koja je navela društvo da bude u potrazi za drugačijim, boljim i odgovornijim načinima poslovanja;

- poslovni uspeh socijalnih preduzeća, koja su nastavila da napreduju uprkos otežanim 
initiator of the micro-crediting idea, which has to date granted credits in the amount of over 7.5 million EUR to the poor people, among them 97\% being women.

\section{Social Enterprises in the European Union}

In Western Europe, social enterprises appeared for the first time in late 1970s, when the first indicative forms appeared illustrating the impotence of the nation state, through its regulatory framework, to cater for the needs of all of its citizens, fight the issue of growing inequality and social inclusion, mainly caused by the fall in economic growth and employment. Growing interest for social enterprises which appeared recently was caused by the recognition of its capacities to overcome economic and social problems which the public and business sectors were not able to resolve. In Europe, at present, there are over 40 different forms of association in the field of social economy, with innovative approach to the solution of problems in the domain of social services, like the education, healthcare, environment protection, housing and fair market conditions. European continental enterprises, according to the field of operation, may be classified into three groups (Group 484, 2010):

- Enterprises offering services to the most vulnerable population categories, or services of public interest (for example, children care, disabled persons care, daily stay centres, home assistance care);

- Enterprises engaged in work integration of the members of the least-employable and marginalized social groups that are offering products/services on the market, while allocating their gain into additional training of their members and improvement of their social status. In order for an enterprise to acquire fiscal benefits and obtain the status of a social enterprise, the minimum criterion prescribed is the number of people form the marginalized groups in the total number of workforce employed;

- Enterprises operating in the social economy non-traditional fields, such as local development, offering of cultural services, environment protection, etc.
It is estimated that the social entrepreneurship sector in the world is employing some 40 million people, wherein different forms of social entrepreneurship the European Union are making some 2 million commercial societies, which is $10 \%$ of the total number. In the United Kingdom, social enterprises today account for some $5 \%$ of all the companies and with the earnings of over 8 billion pounds sterling annually are creating some $1 \%$ of the total annual national product of the country. In Italy, in 1991, some form of a "Social Cooperative" was introduced in order to define legal framework for individual activities of the social enterprises, primarily in the field of social services and employment of the members of vulnerable social categories. It is a predominant form of social enterprise in Italy, with 200,000 employed, 1.5 million users and the growth rate of $15-30 \%$ per year. In Portugal, what was introduced was a form of "Social Solidarity Cooperative" that offers support to the vulnerable social categories and under developed social communities. France has also introduced, in the year 2001, a form of "Cooperative Society of Collective Interest" recognizing the importance of social entrepreneurship for the national economy. Regarding financing, social enterprises have a priority in the regional policy of the European Union, through the European Social Fund and the European Regional Development Fund.

It may be said that some of the reasons for the growing presence of the social enterprises in the world are the following factors (Smart collective, 2013):

- Economic crisis which had induced the society to search for a different, better and more responsible manner of business operation;

- Business success of social enterprises which are continuing to progress in spite of deteriorating business environment in the international economy;

- Growing tendency of the non-governmental sector to become sustainable in future by engaging in some of the commercial activities;

- Awareness and interest of consumers in how their choice in buying is impacting others. Consumers wish to know the origin of the 
uslovima poslovanja u međunarodnoj ekonomiji,

- rastuća težnja nevladinog sektora da u budućnosti bude održiv baveći se nekom komercijalnom aktivnošću,

- svest $\mathrm{i}$ interes potrošača o tome kako njihovi izbori u kupovini utiču na druge. Kupci žele da znaju odakle dolaze proizvodi koje kupuju, da li su imali negativan uticaj na društvo, životnu sredinu i kakvi su uslovi rada onih koji su ih proizveli,

- kupci koji žele da iskoriste svoju kupovnu moć doprinoseći da svet bude bolje i održivije mesto za život,

- poslovni sektor koji traga za novim, inovativnim načinima i rešenjima koji treba da doprinesu društvenim promenama.

Kako pokazuju iskustva zemalja u kojima je ovaj organizacioni oblik već duže zastupljen, osnovna korist po ekonomiju i društvo je u tome što socijalna preduzeća podstiču pozitivne društvene promene i inkluziju, podržavajući civilno društvo, ekonomsku emancipaciju ugroženih grupa, ekološki i ekonomski razvoj. Socijalna preduzeća mogu da ojačaju privredu, otvore nova radna mesta, pomognu u rešavanju društvenih problema preispitujući neke od aktuelnih politika i pomažući vladama da unaprede način organizacije i pružanje javnih usluga. Socijalna preduzeća takođe mogu da uzdignu nivo etičkih standarda poslovanja i sveukupne društvene odgovornosti poslovnog sektora.

\section{Pojavni oblici i forme socijalnog preduzetništva u Srbiji}

Organizacije koje se mogu smatrati socijalnim preduzećima u Srbiji sve više počinju da privlače pažnju kao potencijal koji može da ublaži posledice tranzicije i pruže mogućnost zapošljavanja. Najveće preporuke za dalji razvoj socijalnog preduzetništva u Srbiji ogledaju se $\mathrm{u}$ nedovoljnom poznavanju poslovnih veština budućih (socijalnih) preduzetnika, kao i nepostojanje sistemske i finansijske podrške. Pored toga, u Srbiji nedostaje i pravni okvir za socijalno preduzetništvo, uz administrativne povlastice i poreske olakšice. Kroz pojam društveno odgovornog poslovanja $\mathrm{u}$ formi saradnje sa poslovnim sektorom, može doći do ubrzanja razvoja socijalnog preduzetništva, tako što bi se npr. socijalna preduzeća uključila u lanac nabavke društveno odgovornih preduzeća. Potom, rukovodioci preduzeća mogu da pružaju i poslovno mentorstvo mladim socijalnim preduzetnicima, a banke povoljnije mikro-kreditiranje. U Srbiji još nije donet zakon kojim bi se uredila ova oblast, ali se socijalno preduzetništvo praktikuje registracijom određenog tipa udruženja, kroz zadruge u oblasti poljoprivrede, ekologije, turizma i zanatstva. Zbog toga, nužno je uzeti u obzir više različitih zakona, i to: Zakon o profesionalnoj rehabilitaciji i zapošljavanju osoba sa invaliditetom, Zakon o udruženjima, Zakon o privrednim društvima, Zakon o zadrugama, Zakon o zadužbinama i fondacijama i Zakon o volontiranju. Zakonom o profesionalnoj rehabilitaciji i zapošljavanju osoba sa invaliditetom, prvi put u Srbiji uvedena je mogućnost organizovanja socijalnog preduzeća, kao vid zapošljavanja osoba sa invaliditetom. Istraživanje koje je sprovela Grupa za razvojnu inicijativu "SeCons" pod nazivom „Mapiranje socijalnih preduzeća u Srbiji“ pokazalo je da u Srbiji ima oko 1.160 preduzeća koja mogu da se nazovu socijalnim, među kojima su najbrojnije upravo zadruge, koje čine $78 \%$ od ukupnog broja (najveći broj bavi se poljoprivrednom delatnošću ili posredovanjem pri zapošljavanju mladih osoba iz marginalizovanih grupa). Potom slede udruženja građana, koja čine 14\% ovih organizacija, među kojima dominiraju ona koja pružaju podršku ranjivim grupacijama ili se bave ekologijom i lokalnim razvojem.

Iz svega navedenog, može se zaključiti da socijalno preduzetništvo predstavlja neiskorišćenu mogućnost za Srbiju da smanji siromaštvo, nezaposlenost i društvenu isključenost marginalizovanih grupa. Ipak, postoje projekti i inicijative vredne pažnje:

1. nedavnoje pokrenuta prva nacionalna mreža socijalnih preduzeća (SENS) koja danas okuplja 30 srpskih socijalnih preduzeća. Mreža nastoji da obezbedi svojim članicama edukaciju, stručne savete i promociju u svim fazama pokretanja i vođenja posla. Članstvo je besplatno i otvoreno za sva socijalna preduzeća, koja na ovaj način imaju mogućnost da se promovišu kod potencijalnih kupaca. 
products that they are buying, whether they had a negative impact of society, environment and what are the labour conditions of those who have produced them;

- Consumers who wish to use their buying power to contribute towards the world becoming a better place and a more sustainable place for living;

- Business sector in quest for new, innovative ways and solutions that should contribute to the social changes.

The experience of countries that are having this organisational form in place for some time now has shown that the fundamental benefit for the economy and society is that the social enterprises are instigating positive social changes and inclusion, in support of civil society, economic emancipation of vulnerable groups, but also environmental and economic development. Social enterprises can reinforce the economy, open new jobs, assist in the solution of social problems by re-examining some of the current policies and aiding governments to promote the way public services are organised and offered. Social enterprises can also upgrade the level of ethical business standards and of the overall social responsibility of the business sector.

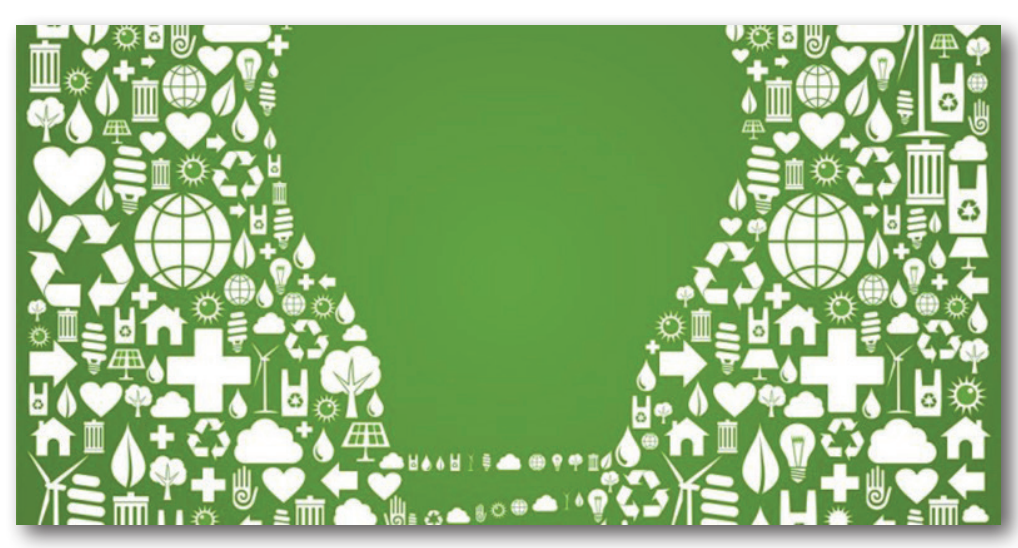

\section{Manifestations and forms of social entrepreneurship in Serbia}

Organisations that may be deemed to be social enterprises in Serbia are increasingly drawing the attention as a potential that may mitigate effects of transition and offer new options for employment. The best recommendation for further development of social entrepreneurship in Serbia is reflected in an insufficient knowledge of business skills of the future (social) entrepreneurs, just as the absence of systemic and financial support. In addition, what is lacking in Serbia is the legal framework for social entrepreneurship, together with administrative facilities and tax benefits. Through the notion of the socially responsible business in the form of cooperation with the business sector what can ensue is an accelerated development of social entrepreneurship, for example in the form of social enterprises joining in the supply chain of the socially responsible enterprises. Managers of enterprises in this case may also offer business mentoring of the young entrepreneurs, while the banks can provide softer micro-crediting facilities. In Serbia, to date, no law was passed that would engage in regulating this field, but the social entrepreneurship is being practiced through registration of a certain type of association, through the cooperatives in the field of agriculture, environment protection, tourism or arts and crafts. Therefore, it is necessary to take into consideration several different laws, as follows: Law on professional rehabilitation and employment of disabled persons, Law on Associations, Law on Commercial companies, Law on Cooperatives, Law on Endowments and Foundations, and Law on Voluntary Action. The Law on Professional Rehabilitation and Employment of Disabled Persons has introduced in Serbia, for the first time, the option of organising a social enterprise as the form of employment of disabled persons. Research conducted by the development initiative group "SeCons" under the title "Mapping of social enterprises in Serbia" has shown that there are some 1,160 enterprises in Serbia that may be called the social ones, among them the most numerous being actually the cooperatives, accounting for $78 \%$ of the total number of enterprises (the highest number being engaged in agriculture or mediation in employment of young persons from the marginalized groups). What follows are the civic associations making up $14 \%$ of these organisations, among them the dominant ones 
2. osnovana je Koalicija za razvoj socijalnog preduzetništva - mreža organizacija posvećenih unapređenju i razvoju ove vrste poslovanja u Srbiji. Osnivači Koalicije su Balkanski fond za lokalne inicijative, Evropski pokret u Srbiji, Smart kolektiv, Inicijativa za razvoj i saradnju Srbije i Grupa 484.

3. dobar primer iz domaće prakse je pokretanje mesečnog časopisa "Lice ulice", koji na mestima velike posećenosti prodaju mladi ljudi iz marginalizovanih grupa, koji zbog manjka radnih kvalifikacija ili predrasuda poslodavaca retko imaju mogućnost zapošljavanja.Časopisje rezultatzajedničkog rada nekoliko organizacija civilnog društva i pojedinaca; Smart kolektiva, Centra za integraciju mladih, YUSTAT Centra, Radne organizacije i profesionalnog glumca (humaniste Branislava Trifunovića). Cena časopisa je 100 dinara, gde polovina iznosa pripada prodavcima, čime im je omogućeno da steknu određeni nivo prihoda. Ostatak novca od prodaje upotrebljava se za dodatnu obuku samih prodavaca i razvijanje novih projekata za integraciju marginalizovanih grupa.

4. socijalna ekološka kooperativa "Eko bag“ koju je pokrenula nevladina organizacija "Inicijativa za razvoj i saradnju“, za proizvodnju torbi, novčanika od recikliranog materijala, prvenstveno od iskorišćenih reklamnih panoa. „Eko bag“ pripada grupi ekoloških socijalnih preduzeća za radnu integraciju. U prvoj fazi formiranja preduzeća, uz saradnju sa Nacionalnom službom za zapošljavanje, izabrano je 30 žena koje su ostale bez posla nakon privatizacije preduzeća iz tekstilnog sektora, i koje su potom prošle obuku da bi svoja postojeća znanja prilagodile radu sa plastičnim folijama, kao i o razumevanju preduzetništva, finansija i marketinga. Na taj način, "Eko bag“ promoviše socijalno preduzetništvo u Srbiji, doprinosi razvoju reciklažne industrije i brige društva za životnu sredinu, istovremeno podstičući društvenu odgovornost poslovnog sektora.

5. društvena kooperativa „Vivere“ osnovana je u Kragujevcu od nekoliko nezaposlenih žena i roditelja dece sa invaliditetom, koji su u Italiji prošli specijalnu obuku. Oblast delovanja kooperative je pružanje socijalnih usluga i integracija osoba sa invaliditetom, koja nije dovoljno regulisana od lokalnih vlasti. Kasnije, u saradnji sa lokalnim vlastima, „Vivere“ je pokrenuo dnevni boravak u kojem aktivno učestvuju i volonteri. Pored dnevne brige, korisnicima se pružaju i usluge radne terapije, pomoć u ličnoj higijeni i zdravstvenojnezi, rekreativna nastava, što sve doprinosi inkluziji osoba sa invaliditetom u zajednicu.

6. dobrovoljno udruženje građana Karitas (Caritas) iz Šapca koje deluje u zdravstvenoj i humanitarnoj oblasti pokrenulo je uslugu hemijskog čišćenja, pranja, sušenja i peglanja veša "Elio“. Žene iz ugroženih društvenih grupa zapošljavaju se sa ciljem da se kroz radno angažovanje vrate $u$ normalne društvene tokove i povrate svoju ekonomsku stabilnost. Ostale ciljne grupe su korisnici programa kućne nege, stara i invalidna lica koja su socijalno ugrožena, i za koje se usluge obavljaju besplatno.

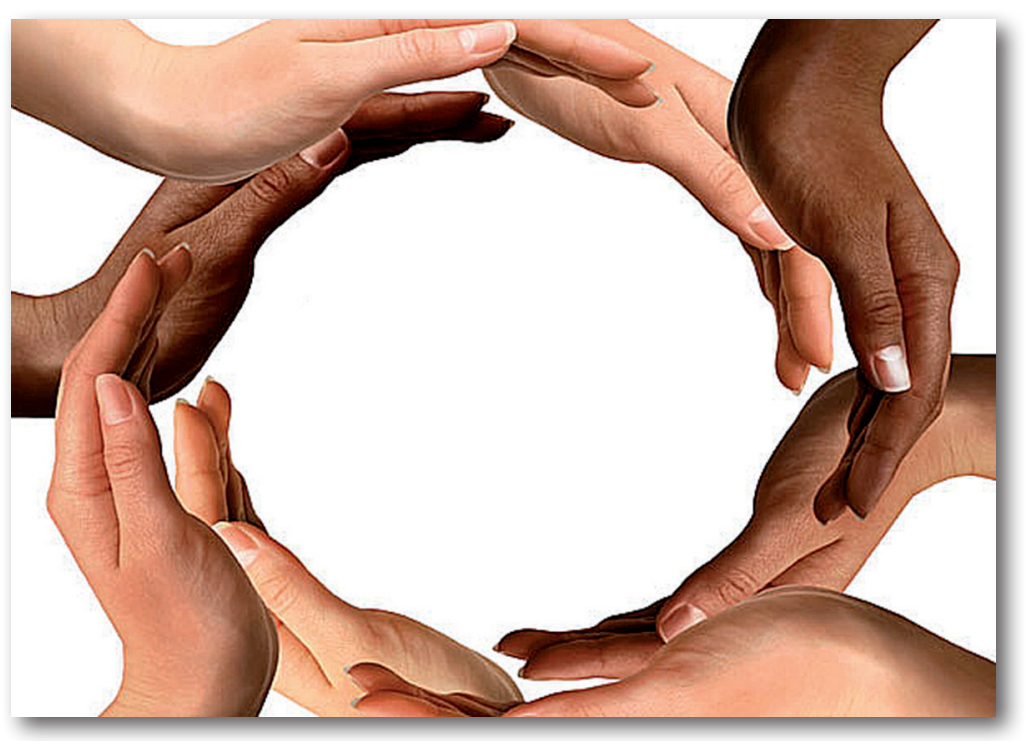

\section{Zaključak}

Socijalni preduzetnici predstavljaju dokaz da finansijski uspeh ne isključuje odgovorno ponašanje prema društvenoj zajednici i životnoj 
offering support to the vulnerable groups or those engaged in environment protection and local development activities.

The above leads to the conclusion that the social entrepreneurship is an insufficiently explored opportunity for Serbia to reduce poverty, unemployment and social exclusion of the marginalised groups. Nevertheless, there are projects and initiatives that are worthy of our attention:

1. Recently an initiative was set in motion for establishment of the first national network of social enterprises (SEBS) which is gathering today 30 Serbian social enterprises. The network is striving to provide for its members education, professional advice and promotion in all the phases of setting up work and business operations. Membership is free of charge and is open for all social enterprises which are in this way having an opportunity to promote their business with potential customers.

2. Coalition for development of social entrepreneurship was established - as a network of organisations devoted to the promotion and development of this type of business in Serbia. Founders of the Coalition are the Balkan Fund for Local Initiative, European Movement in Serbia, Smart Collective, Initiative for development and cooperation of Serbia, and Group 484.

3. Good example of domestic practice is the establishment of the monthly magazine "Face of the Street", which in highly frequented places in town are being sold by young people from the marginalized groups, who are, due to the lack of work qualifications or prejudice by the employers, often left without any options of finding fulltime employment. Magazine is the result of joint effort made by several civic society organisations and individuals: Smart Collective, Centre for Youth Integration, YUSTAT Centre, Work organisation and professional actor. The price of the magazine is 100 dinars where one half of the money is kept by the sellers, so that they can gain a certain level of revenue. The rest of the money from sale is used for additional training of sellers themselves and for the development of new projects aimed at integration of the marginalized groups.

4. Social ecological cooperative "Eco Bag" initiated by the non-governmental organisation "Initiative for Development and Cooperation" for production of bags, wallets from recycled material, primarily from the already used advertising panels. "Eco Bag" belongs to the group of ecological social enterprises for work integration. In the first phase of establishing an enterprise, in cooperation with the National Employment Service, some 30 women was selected who had remained jobless after privatisation of the company operating in the textile sector, and women were sent for training in order to adjust their skills to the work with plastic folia material, but also in order to gain knowledge of entrepreneurship, finances and marketing. In this manner, "Eco Bag" is promoting social entrepreneurship in Serbia, it is contributing to the development of the recycling industry and care of society for the environment protection, at the same time instigating social responsibility of the business sector.

5. Social cooperative "Vivere" was established in Kragujevac joining together several unemployed women and parents of disabled children, who have attended a special training in Italy. The scope of work of this cooperative is offering social services and integration of disabled persons, that is not sufficiently regulated by the local authorities. Later on, in cooperation with the local authorities, "Vivere" established a daily care centre with active participation of volunteers as well. In addition to day care, users of services are offered work therapy, assistance in personal hygiene and health care, recreational programmes, all this in aid of inclusion of the disabled persons in society and social community.

6. Voluntary civic humanitarian association Caritas, from Sabac, acting in the health care and humanitarian field, established a dry cleaning service, washing, drying and ironing of laundry "Elio". Women from vulnerable groups are being employed with the aim, through active employment, to return back to the normal social trends and regain their economic stability. Other target 


\section{Literatura / References}

1. Abu-SaifanSamer, "Social Entrepreneurship: Definition and Boundaries", Technology Innovation Management Review (02/2012), www.timreview.ca (stranici pristupljeno aprila 2013), стр. 25

2. British Council, "Socijalno preduzetništvo - biznis u službi zajednice", www. britishcouncil.org/sr/serbia-projects-social_ enterprise.htm (stranici prisupljeno marta 2013)

3. dr Cvejić Slobodan, dr Babović Marija, Vuković Olivera, „Mapiranje socijalnih preduzeća u Srbiji“, Program Ujedinjenih nacija za razvoj UNDP Srbija (03/2008)

4. Grupa 484 "Socijalno preduzetništvo", elektronski bilten br. 1 (07/2010), str. 3

5. Smart kolektiv, „Biznis po meri čoveka", Vodič za pokretanje socijalnog preduzetništva, Beograd, (2013) str. 20-41

6. Smart kolektiv / Lice Ulice, www. smartkolektiv.org/cms/item/communications/ sr/LICEULICE.html (stranici pristupljeno avgusta 2013)

7. Yunus M., Moingeon B., Lehmann-Ortega L. „Building Social Business Models: Lessons from the Grameen Experience“, Long Range Planning, Elsevier Ltd. (vol. 43, 2010), стр. 308-311 sredini, kao i da društveno-koristan cilj može da bude uspešan poslovni pokretač. Ujedno, socijalna preduzeća mogu biti veoma koristan izvor preduzetničkih ideja u ekonomijama koje prolaze kroz tranziciju, sa visokim stopama nezaposlenosti. Popunjavanjem praznina $u$ pružanju određenih društvenih usluga, uz istovremeno ostvarivanje dobiti i mogućnost angažovanja čitave porodice, su samo neke od odlika socijalnih preduzeća, koja bi mogla da postanu jedan od vodećih modela privređivanja u srpskoj privredi. 
groups are the beneficiaries of the home care programmes, old and disabled persons who are socially vulnerable, with all the services in this field offered free of charge.

\section{Conclusion}

Social entrepreneurs are a proof that financial success does not exclude socially responsible behaviour towards social community and the environment in general, but also that the socially beneficial target can serve as a successful business griver. At the same time, social enterprises can be a very useful source of entrepreneurial ideas in the economies which are passing through transition, having a high unemployment rate. By filling in the gaps in offering certain social services, but at the same time achieving benefits and options of employing entire families, they are only some of the distinctions of social enterprises that could become one of the leading models for business achievements in the Serbian economy. 